\title{
ХАРАКТЕРИСТИКА МОДЕЛІ ФОРМУВАННЯ КОМУНІКАТИВНОЇ КОМПЕТЕНТНОСТІ ЗДОБУВАЧІВ ПОЧАТКОВОЇ ОСВІТИ
}

5. Bernátová, R. (2013). Environmentálna výchova prierezová téma $\mathrm{v}$ základnej škole [Environmental education - a cross-sectional topic in primary school]. Current issues of science and technology subjects and cross-sectional topics in primary education. Online conference. 2325.10.2013, pp.13-25. [in Slovak].

6. Inovovaný školský vzdelávací program pre 1.a 2. Stupeň základnej školy s materskou školou Hôrky [Innovative school development program for 1.a 2. Level of basic school with kindergarten Hôrky]. URL: https:// zshorky.sk/wp-content/uploads/2019/10/ Inovovan $\% \mathrm{C} 3 \% \mathrm{BD}-\% \mathrm{C} 5 \% \mathrm{~A} 1 \mathrm{kolsk} \% \mathrm{C} 3 \% \mathrm{BD}$ vzde1\%C3\%A1vac\%C3\%AD-program-2020.pdf [in Slovak].
7. Plán práce školy v oblasti: environmentálna výchova. Šk. rok: $2020 / 2021$ [School work plan in the area: environmental education. School year: 2020/2021]. Available at: https://zshorky.sk/wp-content/uploads/2020/ $10 /$ Koordin $\% \mathrm{C} 3 \% \mathrm{~A} 1$ torsk $\% \mathrm{C} 3 \% \mathrm{BD}-\mathrm{pl} \% \mathrm{C} 3 \% \mathrm{~A} 1 \mathrm{n}$ environment $\% \mathrm{C} 3 \% \mathrm{~A} 1 \operatorname{lna}-\mathrm{v} \% \mathrm{C} 3 \%$ BDchova-2020-21.pdf [in Slovak].

8. Štátny vzdelávací program pre 2. stupeň základnej školy v Slovenskej republike ISCED 2 - nižšie sekundárne vzdelávanie [State educational program for the 2nd level of primary school in the Slovak Republic ISCED 2 - lower secondary education]. Available at: https:// www.statpedu.sk/files/articles/dokumenty/statnyvzdelavaci-program/isced2_spu_uprava.pdf_[in Slovak].

Стаття надійшла до редакції 26.11.2020

УДК 373.3.016:81-028.3

DOI:

Галина Подановська, викладач Педагогічного фахового коледжу Львівського начіонального університету імені Івана Франка

\section{ХАРАКТЕРИСТИКА МОДЕЛІ ФОРМУВАННЯ КОМУНІКАТИВНОЇ КОМПЕТЕНТНОСТІ ЗДОБУВАЧІВ ПОЧАТКОВОЇ ОСВІТИ}

Стаття присвячена проблемі аналізу експериментальної моделі формування комунікативноі компетентності здобувачів початкової освіти. Виокремлено основні компоненти моделі, підкреслюється їх важливість у прочесі формування комунікативної компетентності учнів початкової школи. Автор наголошує на взаємозв'язку компонентів моделі, які лише в комплексі дозволять домогтися більш високих навчальновиховних результатів в порівнянні з традиційною методикою підготовки кваліфікованого читача.

Ключові слова: модель; комунікативна компетентність; здобувачі початкової освіти; вчитель початкових класів; кваліфікований читач; літературне читання; уроки роботи з дитячою книжкою.

Puc. 1. Лim. 7.

Halyna Podanovska, Lecturer of Pedagogical Professional College of Lviv Ivan Franko National University

\section{CHARACTERISTIC OF THE MODEL OF THE FORMATION OF COMMUNICATIVE COMPETENCE OF PRIMARY SCHOOL PUPILS}

The article deals with the problem of the analysis of experimental model of the formation of the communicative competence of primary school pupils.

It is stated that nowadays great attention is paid to the acquiring of key competences by a person that are to provide his/her direction in a modern world, working out common strategy of constructive interaction with other people on the basis of mutual acceptance and mutual understanding as well as programming of the process of communication with them avoiding stable behaviour stereotypes. In this context the necessity to acquire one of key competences, communicative, is put on the first place, as with the help of the personality's ability and readiness to set and supply constructive interpersonal contacts and get the answer to necessary information is provided.

Though, the survey of the primary school teachers' experience shows that in a real educational process at the lessons of literary reading and work with children's book, the formation of communicative competence is often fragmentary without a whole system and necessary complexity of content and character of children's educational activity. Taking into consideration all the points, the need in the development of the model of the formation of communicative competence of primary school pupils arose.

The main components of the model were defined; their short characteristic is provided as well as their importance in the formation of communicative competence of primary school pupils. The author emphasizes the interconnection of the model components that only in complex can lead to higher educational result in comparison with the traditional methods of training of qualified reader.

Keywords: a model; communicative competence; primary school pupils; primary school teacher; qualified reader; literary reading; lessons with children's book. 


\section{ХАРАКТЕРИСТИКА МОДЕЛІ ФОРМУВАННЯ КОМУНІКАТИВНОЇ КОМПЕТЕНТНОСТІЗДОБУВАЧІВ ПОЧАТКОВОЇ ОСВІТИ}

запровадженням положень Концепції Нової української школи [4] та Державного стандарту початкової освіти [2] значна увага педагогічних працівників акцентується на важливості формування комунікативної компетентності учнів.

Засвоєння елементарних норм мовленнєвої культури та літературний розвиток відбуваються у дошкільному віці. Початкова школа закладає основи розуміння мовних законів, особливостей функціонування окремих мовних одиниць у процесі комунікативної діяльності школяра, зокрема на уроках літературного читання та роботи з дитячою книжкою, роботи з інформацією.

У здобувачів початкової освіти формується розгорнута навчальна діяльність (уміння вчитися) шляхом оволодіння організаційними, логікомовленнєвими, пізнавальними, комунікативними і контрольно-оцінними уміннями і навичками. Освітніми результатами цього етапу школи $\epsilon$ повноцінні мовно-мовленнєві, читацькі уміння і навички, узагальнені знання про реальний світ у його зв'язках й залежностях, розвинені сенсорні уміння, мислення, уява, пам'ять, здатність до творчого самовираження.

Формування комунікативної компетентності здобувачів початкової освіти, їх мовномовленнєвої культури у подальшому полегшить дітям адаптацію у суспільстві, допоможе осягнути поняття взаємодопомоги, співчуття, милосердя, совісті, поваги, що є основою високої моральності. “Мовленнєва особистість - це людина, яку розглядаємо з точки зору їі готовності виконувати мовленнєві дії... Мовленнєва особистість характеризується не лише тим, що вона знає про мову, а й тим, як вона може іï використовувати" $[1,11]$.

Аналіз останніх досліджень. Аналіз психолого-педагогічної та методичної літератури засвідчує складність і багатоаспектність проблеми формування комунікативної компетентності здобувачів початкової освіти. За результатами наукового пошуку варто зазначити, що розробка моделі грунтувалася на: психологічних закономірностях загального розвитку дітей і процесів засвоєння ними понять; засадах педагогіки, зокрема дидактики, про основні принципи і методи навчання; теорії літератури (елементах теорії літературознавства).

Частково та фрагментарно зазначене питання розглядалося у працях вітчизняних і зарубіжних педагогів та методистів - А. Алферова, Ц. Балталона, Г. Бєлінського, Ф. Буслаєва, В. Вахтерова, В. Водовозова, В. Голубкова, Є. Грузинського, В. Данилова, В. Острогорова,
М. Рибникової, Є. Рудського, Д. Тихомирова, К. Ушинського, О. Савченко, В. Науменко. І хоча у їхньому творчому доробку питання розвитку літературної освіти розв'язувалося неоднозначно проте їхні ідеї, методичні здобутки стали для нас опорними у пошуку ефективного рішення створення моделі формування комунікативної компетентності молодших школярів, саме у системі літературного розвитку.

Мета статті - розкрити основні компоненти моделі формування комунікативної компетентності здобувачів початкової освіти, встановити взаємозв'язок між ними.

Виклад основного матеріалу дослідження. Дослідження освітнього процесу показало, що основний недолік тричленної схеми підготовки молодшого школяра-читача (уроки навчання грамоти, уроки літературного читання, роботи 3 дитячою книжкою, робота 3 інформацією) у позакласному читанні полягає у тому, що дітей вчать одного - розкодовувати та озвучувати одиниці писемного мовлення (текст літературного твору), а вимагають іншого - інтересу до читання та вміння читати дитячі книжки. При цьому головним завданням у традиційній методиці визначаються чотири якості читання: швидкість, правильність, виразність, свідомість, і жодним чином не йдеться про такі обов'язкові для “інтересу до читання” характеристики читацької діяльності, як знання книжок $з$ доступного кола читання, уміння спілкуватися 3 книжкоюспіврозмовником і працювати 3 книжкоюінструментом. I коли в традиційну для української школи схему підготовки дитини-читача названі, але ще й досі не включені в неї науково обгрунтовані зміни, вона виявилась не зовсім придатною для розв'язання тих завдань, які суспільство поставило перед школою у питанні формування комунікативної компетентності молодших школярів-читачів у XXI ст. Специфіка формування комунікативної компетентності здобувачів початкової освіти дає підставу зробити припущення щодо можливостей удосконалення результатів цього процесу за умов практичного використання ії складових компонентів.

Ключовиммоментомуреалізаціїекспериментального дослідженняє аналіз розробленої моделі формування комунікативної компетентності здобувачів початкової освіти (рис. 1).

В основу моделі формування комунікативної компетентності здобувачів початкової освіти нами був покладений комплексний підхід взаємозв'язок уроків літературного читання та роботи 3 дитячою книжкою, оскільки всі педагогічні умови тісно пов'язані між собою і 


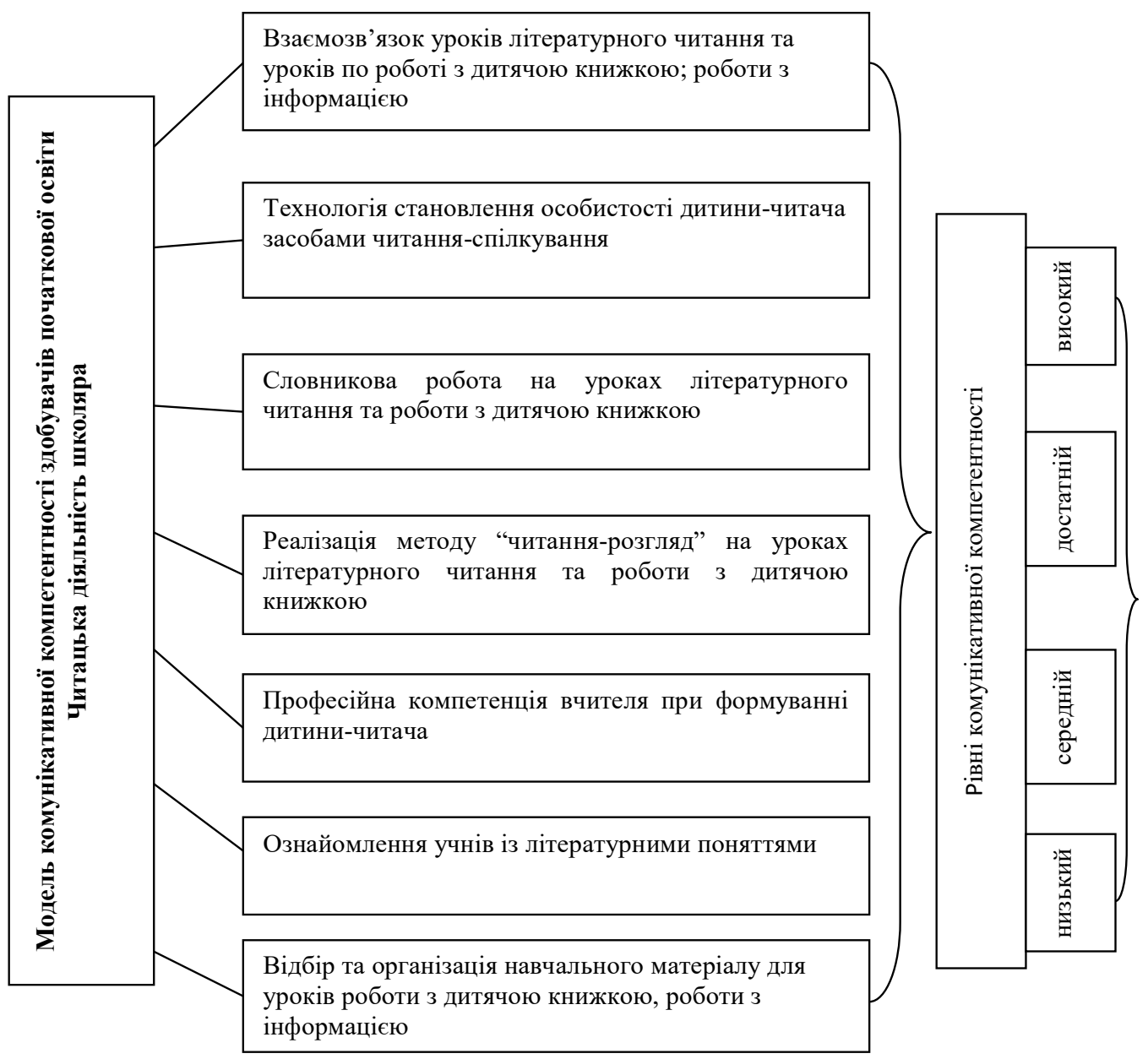

Рис. 1. Модель формування комунікативної компетентності молодших школярів у процесі літературного розвитку

спрямовані на розвиток мовленнєвої особистості. Призначення такого взаємозв'язку, а особливо його змістового компонента - забезпечити учнів міцними літературно-читацькими знаннями:

1) про визначене коло дитячих художніх та науково-пізнавальних книг і їх класифікації за тематичною, жанровою, авторською належністю;

2) про призначення структурних елементів книги $з$ погляду їх значення для проникнення у їі зміст: малюнок (ілюстрація), обкладинка, підписи (назва книги, твору, прізвище автора; сторінки, корінець, заголовок, титульний аркуш, передмова, зміст (перелік творів чи розділів);

3) про види бібліотечно-бібліографічної допомоги: книжкова виставка, рекомендаційний плакат, картотека обкладинок, рекомендаційний список, тематична картотека;

4) про мовно-стилістичні особливості різножанрових літературних творів.

Змістовий тип взаємозв'язків між літературним читанням та роботи 3 дитячою книжкою обумовлюється навчальними програмами, змістом підручників з літературного читання та роботи 3 дитячою книжкою, наявного книжкового фонду, придатного за своїми функціональними властивостями для використання як навчальний матеріал.

Процесуальний тип взаємозв'язку, який входить до механізму інтеграції уроків літературного читання та роботи 3 дитячою книжкою, формується і застосовується у нашій моделі під час безпосередньої взаємодії вчителя та учнів, де реалізуються завдання літературного і мовленнєвого розвитку здобувачів початкової освіти. До складу процесуального типу взаємозв'язку входить комплекс практичних умінь та навичок, які забезпечують ефективне виконання дітьми запропонованих завдань.

Аналіз процесуального компонента уроків літературного читання для 2-4-х класів дозволив окреслити уміння і навички, які беруть безпосередню участь у комунікативній діяльності або активно виконують обслуговуючу, додаткову роль. До процесу формування групи інваріантних умінь, навичок належить такі: 


\section{ХАРАКТЕРИСТИКА МОДЕЛІ ФОРМУВАННЯ КОМУНІКАТИВНОӦ}

КОМПЕТЕНТНОСТІЗДОБУВАЧІВ ПОЧАТКОВОЇ ОСВІТИ

1) читати і розуміти прочитане;

2) сприймати, розуміти, аналізувати й інтерпретувати літературні тексти різних видів із використанням початкових літературознавчих понять;

3) створювати власні висловлювання за змістом прочитаного (прослуханого);

4) здійснювати пошук, добір інформації для розв'язання навчально-пізнавальних завдань.

5) використовувати власний читацький досвід.

Зазначений блок предметних умінь і навичок, які засвоюють здобувачі початкової освіти на уроках літературного читання і роботи з дитячою книжкою та іншими джерелами інформації $\epsilon$ підгрунтям для формування комунікативної компетентності молодших школярів. Цим полегшується їхнє перенесення з уроків літературного читання на уроки роботи з дитячою книжкою та з інформацією і навпаки.

У забезпеченні тісних внутрішньопредметних зв'язків між уроками літературного читання та роботи з дитячою книжкою поряд із змістовим та процесуальним типами важлива роль відводиться взаємозв'язкам мотиваційного типу. "Не маючи можливості заглянути у внутрішній зміст дій і вчинків дитини, - писав С. Рубінштейн, - в мотиви його діянь і внутрішнє ставлення до завдань, які перед нею ставляться, вихователь, зазвичай, працює наосліп” [7, 232]. [Важливість цього положення проявляється у навчальному процесі у ставленні учнів до навчальної діяльності взагалі, а також до книги як джерела знань, досвіду, написаному і наданому в загальне користування, в результаті використання якого виховуються життєві ідеали дітей. Це викликає необхідність встановлення такої взаємодії, співпраці вчителя та учнів, на основі якої забезпечується творча продуктивна навчальна діяльність, формуються читацька самостійність та комунікативна компетентність.

Наступним компонентом моделі формування комунікативної компетентності здобувачів початкової освіти на основі взаємозв'язку уроків літературного читання та роботи 3 дитячою книжкою є технологія становлення особистості дитини-читача засобами читання-спілкування і засвоєння читання як особистої співпраці 3 книжкою-співрозмовником. Так, сучасна технологія формування дитини-читача - це доцільна організація практики навчання читанняспілкування; це науково обгрунтована допомога вчителя дітям, які повинні захотіти і навчитися самих себе вчити читати, звикнути занурюватися у світ книг, полюбити “ритися в книгах", щоб вибрати потрібного співрозмовника і самостійно, але повноцінно (на межі особистих можливостей в даний момент) розмовляти 3 книгою, коли є час або коли це читачеві потрібно.

Читання здатне відкрити читачеві багатство і красу мови, тим самим збагатити його комунікативний потенціал: дитина отримує більше можливостей для самовираження, стає комунікативно успішнішою - у цьому полягають ціннісні чинники читання-спілкування. За допомогою читання учень може відкрити для себе “можливі світи”, 3 якими сам він познайомитися не може. Тут мається на увазі не тільки досягнення науки і техніки, але й продукти творчості, фантазії та уяви авторів, читач художньої літератури, образно кажучи, "проживає" життя разом 3 героями книг, співпереживає їм. Зрештою, читання формує у свідомості завдяки своїй ціннісній орієнтації, певні соціальні моделі людських характерів, зразків поведінки, поведінкових реакцій на різноманітні ситуаційні виклики тощо. Часто ці моделі мають для читача не тимчасове, а універсальне значення. Читання сприяє поширенню цінностей, важливих для суспільства: допомога, співчуття, підтримка, увага до людини, яка потрапила у важку ситуацію [3, 145-147].

Важливим компонентом моделі є словникова робота на уроках літературного читання та роботи з дитячою книжкою. 3 перших днів навчання у школі вчитель повинен працювати над розвитком активного словника учнів початкової школи, бо це дуже знадобиться у майбутньому житті, допоможе їм правильно та впевнено викладати свої думки, вільно спілкуватися 3 однолітками та дорослими. Коли дитина не шукає слів для висловлювання своєї думки, вона позбавлена багатьох комплексів, а тому завжди активна в розмові, оперуючи потрібними словами і мовними зворотами. А такий результат досягається тоді, коли дитина не тільки чує і бачить слово, а відчуває і розуміє його значення, знає, коли і як це слово треба вжити.

Робота 3 книжкою-об'єктом і книжкоюспіврозмовником складає сутність методу “читання-розгляд”, оскільки взаємодія цих двох процесів при звертанні до книжок забезпечує дітей фактичним матеріалом, який дає змогу вдумливо i творчо читати закодоване у книжці “чуже" мовлення, вслуховуватися у стиль цього мовлення, його інтонацію і давати йому власну естетичну оцінку. Окрім того, метод “читання-розгляд” при його точному застосуванні $є$ гарантом ретельного спостереження дітей над мовою книжки, без чого неможливе прогнозування ії̈ змісту. Цей метод має здатність перетворюватися на внутрішню дію - 


\section{ХАРАКТЕРИСТИКАМОДЕЛІ ФОРМУВАННЯ КОМУНІКАТИВНОӦ КОМПЕТЕНТНОСТІЗДОБУВАЧІВ ПОЧАТКОВОЇ ОСВІТИ}

мимовільно передбачати до читання і тему, i форми спілкування з книжкою-співрозмовником, які потім стають професійною навичкою для будьякого кваліфікованого читача. Цей метод незамінний і як база для розширення в учнів пасивного читацького кругозору. А в сукупності 3 логікою правильної читацької діяльності саме метод “читання-розгляд” і забезпечує формування у здобувача початкової освіти на кожному етапі навчання доступного і вкрай необхідного йому рівня психічного розвитку - психічного новоутворення, яке науково обгрунтоване і назване “читацька самостійність".

Наступним компонентом нашої моделі $\epsilon$ професійна компетенція вчителя при формуванні дитини-читача. Зауважимо, що професійна готовність вчителя до навчання дітей читання-спілкування разом з наявністю системи дитячих книг як основного навчального матеріалу та навчанням дітей читацької діяльності відразу у всіх іiї аспектах, починаючи з першого уроку, утворюють типові умови навчання читанняспілкування - комплекс факторів, що становлять собою нероздільну єдність, і лише в таких рамках може відбуватися їх продуктивна взаємодія і взаємозв'язок.

Так, мінімальною базою професійної компетенції вчителя слід уважати: 1) знання дитячих книг 3 кола читання молодших школярів та володіння книгою як основним професійним інструментом; 2) знання теорії формування типу правильної читацької діяльності, основ теорії літератури та володіння сучасними технологіями формування особистості дитини-читача засобами навчання читання; 3) професійну дисципліну i вміння науково обгрунтувати кожне своє методичне рішення.

Зазначимо, що сутність специфіки професійних компетенцій вчителя початкових класів полягає у тому, що, на відміну від учителів-предметників, їхню кваліфікацію визначає не рівень володіння фундаментальними науковими знаннями 3 якоїсь галузі об’єктивної дійсності, а вміння користуватися специфічними інструментами, які організовують і спрямовують індивідуальне оволодіння кожною дитиною тією чи тією життєво важливою діяльністю. Таких специфічно спеціальних професійних інструментів у вчителя початкових класів два, а саме: власне усне мовлення і писемне “чуже” мовлення, тобто літературні тексти, які є основним змістом дитячих книжок.

Професійні компетенції вчителя початкових класів пов'язані 3 формуванням в учнів літературознавчої компетенції.
До детального розгляду саме літературознавчої компетенції нас спонукав літературний розвиток молодших школярів, який у методичній науці розглядається як віковий $\mathrm{i}$ навчальний процес та характеризується за декількома аспектами. По-перше, як розвиток здібності безпосередньо сприймати мистецтво слова й формування складних умінь свідомо аналізувати й оцінювати прочитане, керуючись естетичними критеріями. По-друге, як процес розвитку власне літературної творчості дітей.

Літературознавча компетенція як основа літературного розвитку молодших школярів зумовлює достатній читацький досвід молодших школярів, усвідомлення жанрової специфіки твору; визначення на практичному рівні і усвідомлення таких понять, як тема, основна думка, жанрова специфіка твору,сюжет, композиція, автор твору, система персонажів. Важливе місце у цьому переліку належить мові твору. Володіння літературними поняттями дає можливість дитині глибоко осмислити художній твір, відтворити систему художніх образів та розширити коло читання, охопивши жанрові форми художньої, науково-пізнавальної, довідкової літератури, української і зарубіжної $[6,20]$.

Професійні компетенції вчителя початкових класів пов'язані 3 ретельним відбором навчального матеріалу для уроків роботи з дитячою книжкою, розглядом кола читання, адресованого сучасним молодшим школярам, i тенденції його розширення та розвитку.

Так, книга у процесі становлення особистості засобами читання-спілкування - це, по-перше, матеріальний об'єкт, що містить у собі соціальноморальний досвід, який забезпечує зв'язок поколінь і пропонує читачам матеріал, над яким і за допомогою якого треба вчитися думати про себе і про світ; по-друге, це співрозмовник, який передає читачеві соціально-моральний досвід, який особливо необхідний дітям 6-9 років для їх особистісно-орієнтованого становлення як громадян, членів певного суспільства; по-третє, це інструмент, який допомагає читачеві повноцінно почерпнути відсутній у нього соціально-моральний досвід, оскільки зміст цього досвіду отримав явне функціональне вираження у визначених елементах і службах книги та літературному творі.

Висновок. Отже, перераховані вище компоненти в єдності склали цілісну структуру моделі комунікативної компетенції у процесі літературного розвитку здобувачів початкової освіти, приведення в дію якої за допомогою експериментального навчання дасть змогу 
домогтися більш високих освітніх результатів в порівнянні з традиційною методикою підготовки кваліфікованого читача, визначити рівні комунікативної компетентності учнів.

\section{ЛІТЕРАТУРА}

1. Вашуленко М.С. Методика викладання української мови в початковій школі. Київ, 2008. $318 \mathrm{c}$.

2. Державний стандарт початкової освіти (2018). URL: https://www.kmu.gov.ua/ua/npas/prozatverdzhennya-derzhavnogo-standartupochatkovoyi-osviti (дата звернення: 10.02.2021).

3. Коваль Г. П., Іванова Л.І., Суржук Т. Б. Методика читання. Тернопіль : Навчальна книга - Богдан, 2010. 280 с.

4. Концепція Нової української школи. URL: https://mon.gov.ua/ua/tag/nova-ukrainska-shkola (дата звернення: 14.12.2020).

5. Ткачук Г.П. Дитяча книжка і проблеми становлення читацької самостійності у молодших школярів. Збірник наукових праць Кам'янецьПодільського державного університету. Серія педагогічна. 3-41-Випуск XIII. Кам'янецьПодільський : ФОП Сисин О.В., 2007. С. 66-70.

6.Цимбалюк Л.Проблеми ведення літературознавчої пропедевтики в початкових класах. Початкова школа. 2000. № 11. С. $19-25$.

7. Рубинштейн С.Л. Проблемы общей психологии. Москва: Педагогика, 1973. 424 с.

\section{REFERENCES}

1. Vashulenko, M.S. (2008). Metodyka vykladannia ukrainskoi movy $\mathrm{v}$ pochatkovii shkoly [Methods of teaching the Ukrainian language in primary school]. Kyiv, 318 p. [in Ukrainian].

2. Derzhavnyi standart pochatkovoi osvity (2018). [State standard of primary education]. Available at: https://www.kmu.gov.ua/ua/npas/prozatverdzhennya-derzhavnogo-standartupochatkovoyi-osviti (Accessed 10 Feb. 2021) [in Ukrainian].

3. Koval, H. P., Ivanova, L.I. \& Surzhuk, T. B. (2010). Metodyka chytannia [Methods of reading]. Ternopil, 280 p. [in Ukrainian].

4. Kontseptsiia Novoi ukrainskoi shkoly [The concept of the New Ukrainian school]. Available at: https://mon.gov.ua/ua/tag/nova-ukrainska-shkola (Accessed 14 Dec. 2020) [in Ukrainian].

5. Tkachuk, H.P. (2007). Dytiacha knyzhka i problemy stanovlennia chytatskoi samostiinosti u molodshykh shkoliariv [Children's book and the problems of reader independence in junior high school]. Collection of scientific works of Kamyanets-Podilsky State University. The series is pedagogical. 3-41 Issue XIII. Kamyanets-Podilsky, pp. 66-70. [in Ukrainian].

6. Tsymbaliuk, L. (2000). Problemy vedennia literaturoznavchoi propedevtyky v pochatkovykh klasakh [Problems of literary propaedeutics in primary school]. Elementary School, No. 11, pp. 19-25. [in Ukrainian].

7. Rubynshtein, S.L. (1973). Problemy obshchei psykholohyy [Problems of general psychology]. Moscow, 424 p. [in Russian].

Стаття надійшла до редакції 08.12.2020

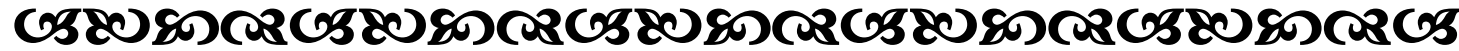

"Я̆ мислю- отже існую!"

Рене Dекарт

франиузький фінософ, фоізик, бізіолог

“У природі қожне явище - заплутаний клубок, в суспільстві қожна людина - қамінчик в мозайчному візерунку. I в світі ббізиному, $i$ в світі духовному все переплетено, немає нічого бездомішкового, нічого відоқремленого".

Нікола де Жальбор

французький білософ-мораліст, письменник

“Будь-яқе людське знання починається з інтуїиї, переходить до понять і завериується ідеями".

Іммануӥл Кант

німеиький ббілособ

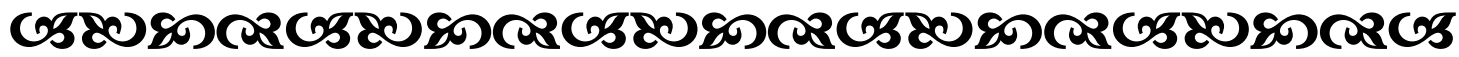

Молодь і ринок №1 (187), 2021 